\title{
S100B Positive
}

National Cancer Institute

\section{Source}

National Cancer Institute. S100B Positive. NCI Thesaurus. Code C153499.

An indication that expression of S100B has been detected in a sample. 